\title{
EFFICIENCY OF DIFFERENT TECHNIQUES OF CATTLE TREATMENT WITH INSECTICIDES
}

\author{
Anatolii Shevchenko \\ Private Company "Tores- $N$ " \\ 16 Haharina str., Brovary, Kyiv region, Ukraine, 07400 \\ anshevch74@gmail.com \\ Raissa Slobodian \\ Department of Parasitology \& Tropical veterinary \\ National University of Life and Environmental Sciences of Ukraine \\ 16 Polkovnyka Potechina str., Kyiv, Ukraine, 03041 \\ sunraissa@gmail.com
}

\begin{abstract}
These researches were carried out on the use of insecticide for infected animals, depending on its quantity (volume), shape and disperse of the drop during spraying. We used the solution of Ektosan ${ }^{\mathrm{TM}}$ (LTD "Brovapharma", Ukraine) in dilution 1:1000, with spraying of external usage twice, against Bovicola bovis Linnaeus, 1758, (Trichodectidae, Mallophaga) spontaneous infected lactating dairy cows of 4-8 years of age and young cattle aged 4-6 to 12 months during 2009-2010 in the State breeding farm "Ploskivske", Kyiv region, and in February-March, 2012 in the private farm "Volyn", Rivne region of Ukraine. A total number of 464 hosts (cows and calves) were examined, out of which 356 animals or $76.72 \%$ were infected by B. bovis. - Efficacy of three techniques of cattle treatment with insecticide was studied. The time-indexes (time-consuming) for treatment and prophylactic manipulations of animals were investigated and recorded.

$100 \%$ efficiency of three techniques with full-volume system sprayer $\left(2000 \mathrm{~cm}^{3} / \mathrm{animal}\right)$, medium-volume sprayer $\left(250 \mathrm{~cm}^{3} /\right.$ animal $)$ and low-volume sprayer or fine-dispersed atomizer $\left(100 \mathrm{~cm}^{3} /\right.$ animal $)$ was established.

According to the work time consuming, the least time for animals' treatment technique spraying was spent by using a disinfection full-volume system sprayer "DUK". Full time of this manipulation has taken 33 minutes. The most labor-intensive technique was with using a manual low-volume sprayer "Rosynka". The work by this technique has taken 58 minutes, and was by 43.1 and $23.3 \%$ minutes more in comparing to full-volume system and medium-volume system sprayers.

The medium-volume system spraying technique for animals was more economically expedient, in accordance for employees' labor expenses and Ektosan ${ }^{\mathrm{TM}}$ insecticide price.

Keywords: insecticides, Ektosan ${ }^{\mathrm{TM}}$, techniques of treatment, cattle, calves, ectoparasites, Mallophagans or chewing lice, Bovicola (syn. Damalinia) bovis, Ukraine.
\end{abstract}

\section{Introduction}

The chewing lice (Mallophaga) are common parasites of different animals. Most of them infest terrestrial and marine birds, including pigeons, doves, swans, cormorants and penguins. Mallophaga have not been found on marine mammals but only on terrestrial ones, including livestock and pets. Their bites damage cattle, sheep, goats, horses and poultry, causing itch and scratch and arousing phthiriasis and dermatitis. Notably, Mallophagans can vector important parasites, such as the filarial heartworm Sarconema eurycerca. Livestock losses due to chewing lice are often underestimated, maybe because farmers notice the presence of the biting lice only when the infestation is too high [1].

The subject of interest and research are the species of Bovicola bovis Linnaeus, 1758 (family Trichodectidae Kellogg, 1896, suborder Ischnocera, order Mallophaga) in cattle. B. bovis is a permanent ectoparasite, which infects the all aged cattle [2, 3]. It distributed on all continents of the globe, especially in farms with low sanitary and hygienic conditions of maintenance and feeding [4]. Newborn calves are infected from lactating cows at first days of life [4, 5]. Throughout the year, parasites migrate across the entire body surface of the host, choosing an area with the optimal microclimate of the skin $[6,7]$. 
High intensity of infection of permanent or temporary insects causes stress and decrease the resistance of the animal [8]. Up to $25-50 \%$ of daily milking and its fat decrease under insect infection, even up to completely stop milking was noticed. In sick cows were registered abortions, sedation and pathology of calving [9]. Anemia also develops, albumin by high decrease $\mathrm{\gamma}$-globulins in blood serum decreases, which indicates for toxic processes of sick animals [10, 11].

For animals treatment is used external applying all over the hair of body with powder and solutions of insecticides. During farmyard period, livestock management against B. bovis and other ectoparasites is combined with mechanical cleaning and disinfection of premises and care items [12].

Mainly insecticides are used with low-volume technique spraying, by dusting hair, special repellent labels, and parenteral injections of macrocyclic lactones for infected with permanent ectoparasites animals $[13,14]$. Bathing animals' technique with water solution insecticides achieves a high rate of penetration of surfactant molecules and dissolves of the skin fat [15]. Its efficacy depends on the quality of insecticides, structure and overall hair contamination (dirtiness), the type and concentration of surfactant, the temperature of the emulsion and hair moisturizing [16].

Advantages of spraying animals' techniques are prolonged action on insects and low skin penetrability of the insecticide and repellent solutions [17]. It is important the dispersion of a drop of solution during treatment of animals which depends on the used equipment.

In our previous investigations at cattle farms was established, that parasitizing Bovicola insects caused decreasing milking by 7.2-24.1\% in lactating dairy cows [18]. Therefore, the search and introduction of new highly effective insecticides with the appropriate methods of their usage for animals' prevention and treatment against ectoparasites are relevant.

In these studies, were examined the modern spraying techniques on the various strategies available for Mallophagans control in cattle.

\section{Aim of research}

To carry out the study of the efficacy of different techniques treatment against B. bovis in spontaneous infected cattle with insecticide solution, according to its quantity (volume), shape and disperse of the drop during spraying, and time-indexes for manipulation.

\section{Materials and methods}

The studies were carried out with naturally infected by Bovicola parasites lactating dairy cows (4-8-years old) and young cattle (4-6 to 12 months old) at 2 livestock farms: in the State breeding farm "Ploskivske", during winter season, 2009-2010, Kyiv region, and in the private farm "Volyn", in February-March, 2012, Rivne region of Ukraine.

Insects and their larvae were found and determined by external parasitological examination (Yatusevich, 2006) of animals around the area of horn, ears, bottom dewlap, neck, shoulder blades, rump and back, around the tail by plucking or cutting hair, by size $10 \times 10 \mathrm{~cm}$ (used an original stencil frame). Specimens (insects with hair and woollen stuff) determined at day light and under light microscope $(\times 40$ to $\times 100$ magnification) in a Petri dish on a white filter paper. The total number of B. bovis (Infection Intensity, No. of insects per $10 \mathrm{~cm}^{2}$ ), and all infected animals (Prevalence of infection, \%) was calculated.

Bovicola species were studied and identified with determinants proposed by Brihadyrenko (2003) and Fundamentals of taxonomy of insects by Capinera (2008). The digital camera Nikon Coolpix 8400 with optical and digital zoom mounted on the microscope was used for illustrations.

An efficacy of three techniques external spraying of insecticide was studied for cattle treatment $[19,20]$. Solution of Ektosan ${ }^{\mathrm{TM}}$ was prepared freshly, in dilution 1:1000 [21]. The interval period for treatment was 12-14 days (in accordance to lifecycle of B. bovis).

The next three techniques: the full-volume system sprayer "DUK" type (2000 cm $3 /$ animal), the medium-volume sprayer pump system «Quasar» type $\left(250 \mathrm{~cm}^{3} /\right.$ animal $)$, and manual low-volume sprayer or fine-dispersed atomizer "Rosynka" (100 $\mathrm{cm}^{3}$ /animal) were used and compared to each of it. Animals observed on 1, 3, 7, 14, 19, 21 and $28^{\text {th }}$ day of research. The inspection of cut areas of animals' body surface and places around, was performed additionally. 


\section{Results}

A total number of 346 hosts (cows and calves) at the State breeding farm "Ploskivske" and 118 lactating cows, at the private farm "Volyn" were examined, out of which, 71.68 and $100 \%$ respectively, were infected by Bovicola species during winter, 2009-2010 and 2012. The highest intensity of infection estimated by visual scanning and counting in calves was $213.29 \pm 11.89$ (with range of 180-252 insects), in caws it was $10.86 \pm 1.61$ (farm 1), and $220 \pm 12.4$ (farm 2) insects per $10 \mathrm{~cm}^{2}$ area. The lowest intensity of infection in caws was from $0.71 \pm 0.54$ to $1.86 \pm 1.13$, in calves was from $2.43 \pm 0.80$ to $5.43 \pm 1.26$ (farm 1); in cows was $52 \pm 2.16$ insects per $10 \mathrm{~cm}^{2}$ area (farm 2) dependently on the area (in average) (Table 1).

\section{Table 1}

The prevalence and infection intensity of Bovicola bovis with efficacy of different techniques of insecticide solution for cattle treatment at farms of Kyiv and Rivne regions of Ukraine $(\mathrm{M} \pm \mathrm{m})$

\begin{tabular}{|c|c|c|c|c|c|c|c|c|c|c|c|c|c|c|}
\hline \multirow[t]{2}{*}{ Farms } & \multicolumn{2}{|c|}{$\begin{array}{l}\text { No. of hosts } \\
\text { examined }\end{array}$} & \multicolumn{2}{|c|}{$\begin{array}{l}\text { No. of hosts } \\
\text { infected }\end{array}$} & \multirow{2}{*}{$\begin{array}{l}\text { Preva- } \\
\text { lence of } \\
\text { infec- } \\
\text { tion, } \% \\
\text { Max. } \\
\text { per area } \\
\text { Cows }\end{array}$} & \multirow{2}{*}{$\begin{array}{c}\text { Min. } \\
\text { per } \\
\text { area } \\
\text { calves }\end{array}$} & \multirow{2}{*}{$\begin{array}{l}\text { Infection } \\
\text { intensity, } \\
\text { No. of insects } \\
\text { per } 10 \mathrm{~cm}^{2} \\
\text { (mid) } \\
\text { Cows calves }\end{array}$} & \multirow{2}{*}{\multicolumn{2}{|c|}{$\begin{array}{l}\text { Infection intensi- } \\
\text { ty, No. of insects } \\
\text { per } 10 \mathrm{~cm}^{2}\end{array}$}} & \multirow[t]{2}{*}{$\begin{array}{l}\text { Tech- } \\
\text { niques }\end{array}$} & \multirow{2}{*}{$\begin{array}{c}\text { Dosage } \\
\text { and } \\
\text { interval } \\
\text { periods, } \\
\text { cm }^{3} / \text { days }\end{array}$} & \multirow{2}{*}{$\begin{array}{l}\text { Time } \\
\text { for } \\
\text { techniq. } \\
\text { \& treat- } \\
\text { ment, } \\
\text { minutes }\end{array}$} & \multirow{2}{*}{$\begin{array}{c}\text { Ex- } \\
\text { tence } \\
\text { effica- } \\
\text { cy, \% } \\
\text { Day } 21\end{array}$} & \multirow{2}{*}{$\begin{array}{c}\text { In- } \\
\text { tense } \\
\text { effica- } \\
\text { cy, \% } \\
\text { Day } 21\end{array}$} \\
\hline & Cows & calves & Cows & calves & & & & & & & & & & \\
\hline $\begin{array}{l}\text { Farm } 1 \\
\text { "Plo- } \\
\text { skivske" }\end{array}$ & 260 & 86 & 162 & 86 & 62.3 & 100 & $\begin{array}{l}8,5 \pm \\
\pm 2,36-177.8 \pm \\
-10,86 \pm \pm 65.96 \\
\pm 1,61\end{array}$ & $\begin{array}{c}213.29 \pm \\
\pm 11.89\end{array}$ & $\begin{array}{c}2.43 \pm 0.8 \\
+\quad \text { calves) } \\
0.71 \pm 0.54 \\
\quad(\text { cows })\end{array}$ & $\begin{array}{l}\text { Full- } \\
\text { volume } \\
\text { system } \\
\text { sprayer } \\
\text { "DUK" } \\
\text { type }\end{array}$ & $2000 / 14$ & 33 & 100 & 100 \\
\hline $\begin{array}{c}\text { Farm } 2 \\
\text { "Volyn" }\end{array}$ & 118 & 0 & 118 & 0 & 100 & & $\begin{array}{l}220 \pm \\
\pm 12.4\end{array}$ & 240 & $\begin{array}{c}52 \pm 2.16 \\
\text { Low- } \\
\text { volume } \\
\text { sprayer } \\
\text { "Rosynka" }\end{array}$ & $\begin{array}{l}\text { Medium } \\
\text { volume } \\
\text { sprayer } \\
\text { "Qua- } \\
\text { sar" type } \\
100 / 12\end{array}$ & $250 / 14$ & 100 & 100 & 100 \\
\hline
\end{tabular}

The effect of two-fold application of the Ektosan ${ }^{\mathrm{TM}}$ solution (in a dose of $2000 \mathrm{~cm}^{3} / \mathrm{animal}$ ), with usage of the full-volume system sprayer "DUK" type for different aged cattle with the high intensity of infection in conditions of the State breeding farm «Ploskivske» has been recorded. Time spent on processing 10 animals averaged 33 minutes. This spraying technique has contributed to retention of insecticide for a long time in hair with subsequent prolongation of action. Extence efficacy (EE) and Intense efficacy (IE) on $21^{\text {st }}$ day of observation was $100 \%$ (Table 1).

The usage of spraying technique with medium-volume pump sprayer "Quasar" type $\left(250 \mathrm{~cm}^{3} /\right.$ animal) for animals with the high infection intensity was also effective. At the 19-th day of the study (7 days after the second treatment) no Bovicola species in animals were found. Also another technique application with a manual low-volume sprayer "Rosynka" type of insecticide solution $\left(100 \mathrm{~cm}^{3} /\right.$ animal) had a high efficiency and contributed to the release of animals from parasites. It is indicated the insecticidal effect of long-acting of its method as well. The EE and IE of both techniques were $100 \%$.

Spraying techniques in private farm "Volyn" in accordance to time-consuming and labor-intensive processing for lactating cows treatment also was studied.

Two methods with medium-volume and manual low-volume spraying were labor-intensive. Treatment of 10 animals with these methods was 43 and 58 minutes, respectively (Table 1).

The most labor-intensive spraying technique for animal treatment was with using a manual low-volume sprayer "Rosynka" type. The processing for animals by this method showed in 1.76 
and 1.35 more time spent indexes in comparison to full-volume system and medium-volume system sprayers, respectively.

\section{Discussion}

In veterinary medicine exists spraying system treatment of cattle against insects with usage of insecticide solution. It depends from the quantity (volume) of solutions. These techniques are conditionally divided into full-volume spraying system (more than $500 \mathrm{~cm}^{3}$ per adult and $250 \mathrm{~cm}^{3}$ per young cattle, respectively), medium-volume spraying system $\left(100-500 \mathrm{~cm}^{3} /\right.$ adult and $50-250 \mathrm{~cm}^{3} /$ young individuals), low-volume spraying system (10-100 $\mathrm{cm}^{3} /$ adult and $5-50 \mathrm{~cm}^{3} /$ young individuals), and ultralow-volume spraying system (maximum $10 \mathrm{~cm}^{3} /$ adult and $5 \mathrm{~cm}^{3} /$ young individuals) [22].

It is well known, that the prolonged effect of insecticides and repellents with spraying of flying up and sitting on animals insects persists for a longer time. Medicines usage with this method is minimizing their penetration into the body of animals through the skin [23, 24]. It is also important the drops dispersion during spraying in accordance to the type of equipment $[25,26]$.

At the State breeding farm "Ploskivske" during usage of insecticide solution with full-volume system sprayer "DUK" type, the animals long time stayed wet, included their legs (Fig. 1). It means sufficient moistening of the animals' hair and wool stuff, the creation of an appropriate microenvironment on their skin and a constant prolonged action of the insecticide on Bovicola species. For animals inspection and detection of insects, were used the thermic electric lamps. On 19-th and 21-st examination days, insects and their larvae were not found, which indicated the efficacy of this technique.

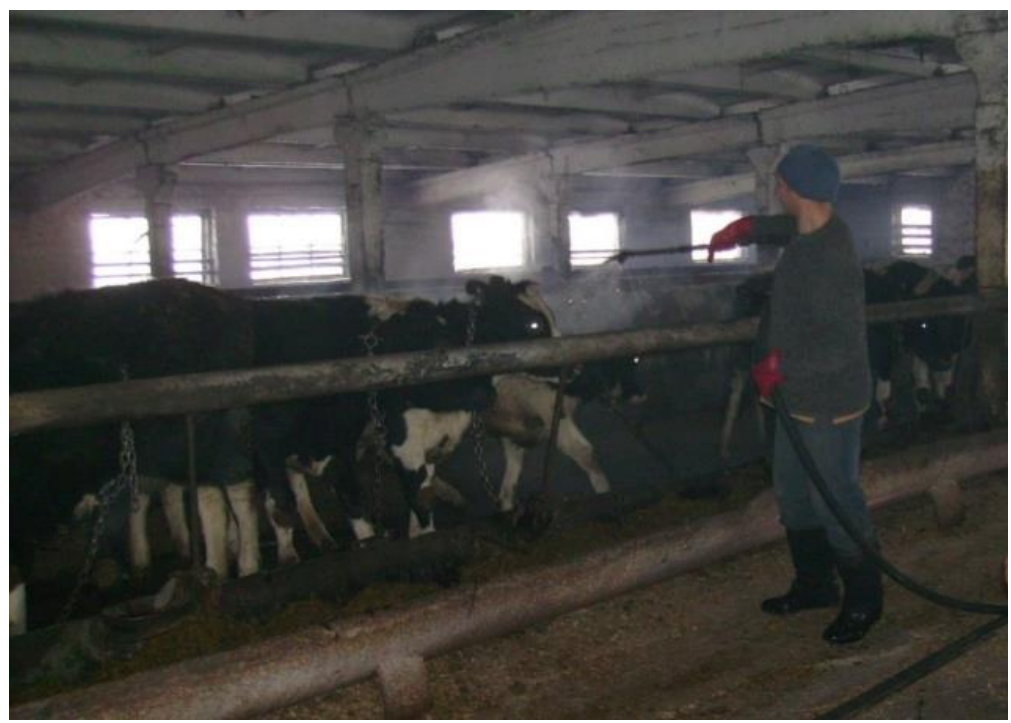

Fig. 1. The full-volume spraying technique of young cattle treatment with system "DUK" type

Taking into account the seasonality and temperature of the environment, the time of day and period of animals treatment were selected especially carefully, guided by the Hydro meteorological Center of Ukraine reports. For that, the therapeutic measures for animals with the high infection intensity, when the ambient temperature was reduced to $4{ }^{\circ} \mathrm{C}$ and lower were not provided. The treatment was carried out only at the favorable conditions of the environment in the premises (above $4{ }^{\circ} \mathrm{C}$ ), in order to prevent wet cooling and infection from pathogens respiratory disease of calves.

A little bit difficult was the use of technique with medium-volume spraying system for lactating dairy cows under the high infection intensity at the private farm "Volyn" (Fig. 2). In this case, it was necessary to spend more time for to fill the insecticidal solution into capacity system, remove off and dress back sprayer device, for each 45-50 animals. Furthermore, it was necessary to force of hand muscles and mechanical pump to pump it to 30 times /minutes to create the operating 
pressure and supplying liquid. This technique had been requiring the certain skills and preliminary familiarization with the instructions for using the sprayer device.

At the same time, an insecticide solution in dose of $250 \mathrm{~cm}^{3}$ per animal, was completely enough for spraying over the animals. Fine drops dispersion at exit of sprayer were provided by its technical characteristics (pressure $0.3 \mathrm{MPa}\left(0.35 \mathrm{~atm}\right.$.), dispersion angle of $60^{\circ}$ and range distance (about $1.8 \mathrm{~m}$ ). All of this allowed a safe distance to us from the animals. Usage of Ektosan ${ }^{\mathrm{TM}}$ solution spraying with medium-volume technique was evenly moisturizing hair and wool stuff. Solution well covered the hair and the skin, without draining to the floor. This spraying technique contributed to the gradual release of animals from parasites and their larvae. After 7 days of two-fold treatment (on 19-th and 21-st day of the study and inspection), alive Bovicola species imago and their larvae have not found.

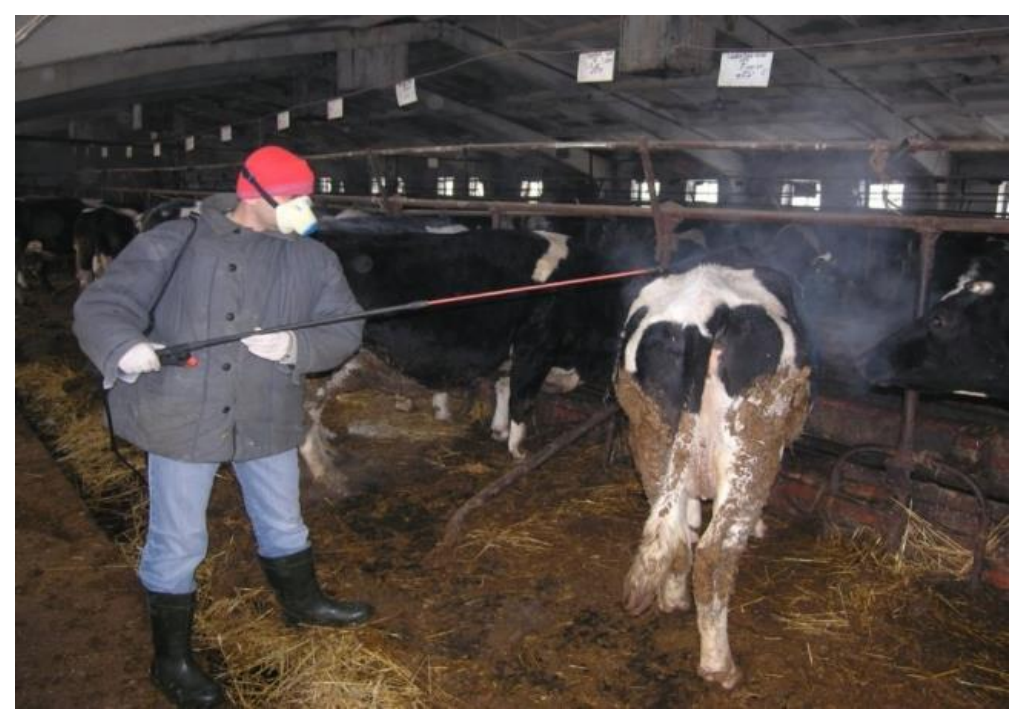

Fig. 2. The medium-volume spraying technique of animals' treatment with pump system “Quasar” type

The most labor-intensive spraying technique for lactating cows' treatment was the processing with insecticide solution by using a manual low-volume sprayer "Rosynka" type (Fig. 3).

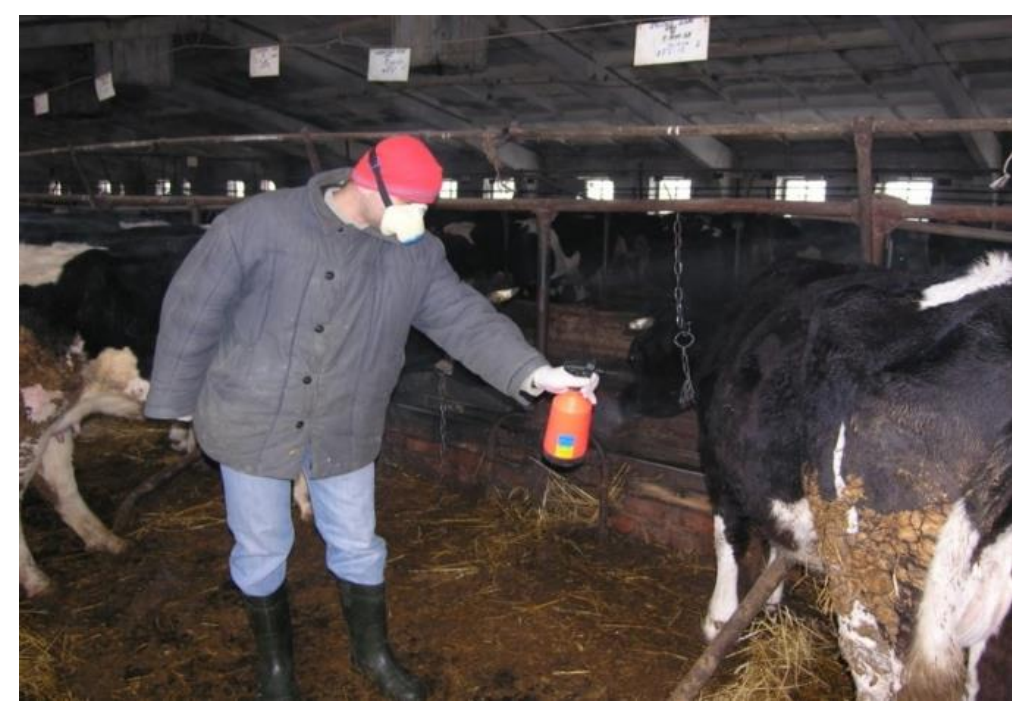

Fig. 3. Cows' treatment technique with using a manual low-volume sprayer "Rosynka"

The peculiarity of this technique was the determination of the biggest accumulation and localization places of parasites on animals. Taking into account that, the main task of treatment is 
to sufficiently moisturize of infected areas animals with a solution. The advantage of this method as a minimally quantity usage of insecticide solution $\left(100 \mathrm{~cm}^{3} /\right.$ animal $)$ for each individual treatment was established.

At the same time, the determination of this manipulation has some difficulties. It consisted in the inconvenience of periodic stops of manipulation before processing of each 4-th animal for to fill a container with solution with extra time. Also, this spraying technique for animal treatment is considered as a labor-intensive, with being in close distance to the animals, what is not safely. After processing of 3 animals there was registered a significant decrease of speed and force pump pressing, which led to an increase in the energy costs and effort of the arm muscles and their tiredness for manipulation.

In comparison of the next two techniques treatment, such as low-volume spraying (a manual sprayer "Rosynka" type) and medium-volume spraying (pump system "Quasar" type) at the same interval period and synchronous manipulation was registered by 1.5 time higher speeding up of qualitative moisturizing animals hair of the latter one.

Thus, to summarize results of investigations with the time-consuming, the financial expenses for animals' treatment and prevention with usage of veterinary Ektosan ${ }^{\mathrm{TM}}$ insecticide solution, the medium-volume spraying technique at the private farm "Volyn" of Rivne region of Ukraine was more economically expedient for cattle.

These treatment and prevention techniques for control Bovicola bovis in cattle could be offered to be used by owners at middle and small private dairy farms in general. The main component of costs also depends on the price of insecticide and possible future losses from the rejecting of products and withdrawal time interval for milk after treatment.

The results of present study indicate, that the usage of Ektosan ${ }^{\mathrm{TM}}$ insecticide with different spraying techniques against Bovicola species parasites can prevent significant economic losses [27], to obtain and to increase milk production for each cow additionally.

\section{Conclusions}

1. The three techniques with full-volume system sprayer $\left(2000 \mathrm{~cm}^{3} /\right.$ animal $)$, medium-volume sprayer ( $\left.250 \mathrm{~cm}^{3} / \mathrm{animal}\right)$ and low-volume sprayer or fine-dispersed atomizer $\left(100 \mathrm{~cm}^{3} / \mathrm{animal}\right)$ with Ektosan ${ }^{\mathrm{TM}}$ insecticide, in dilution 1:1000, against Bovicola bovis with external usage twice for animals, in 12-14-days interval had $100 \%$ effect. Extence efficacy and intense efficacy of these techniques at the 19-th and 21-st day of the study was $100 \%$.

2. The least time-consuming technique of animal treatment spraying in accordance with the working hours was a technique with using full-volume system sprayer "DUK" type.

3. The most labor-intensive spraying technique for animal treatment was with using a manual low-volume sprayer "Rosynka"; used time by this technique is by 43.1 and $23.3 \%$ minutes more in comparison to full-volume system and medium-volume system sprayers.

4. The medium-volume system spraying technique for animals' treatment is more economically expedient technique, in accordance to employees' expenses and Ektosan ${ }^{\mathrm{TM}}$ insecticide price.

\section{Acknowledgements}

Authors express their sincere acknowledgements personally to the professor and Doctor of Veterinary Sciences, director of the scientific and production pharmaceutical veterinary company LTD "Brovapharma”, Andrii V. Berezovskyi (Kyiv, Ukraine), special thanks to professor and Doctor of Veterinary Sciences, Nataliia M. Soroka (Kyiv, Parasitology and Tropical Veterinary Department of the National University of Life \& Environmental Sciences of Ukraine) for the numerous helpful advices; special words of gratitude to all colleagues of laboratory entomological and acarological animals diseases of Rivne Research Station of Epizootology (Institute of Veterinary Medicine of the National Academy of Agrarian Sciences of Ukraine) and to colleagues and doctors of Veterinary Medicine of the livestock farms of "Ploskivske" (State breeding farm) and "Volyn" (private farm) for contribution, assisting and strong supporting during researches. 


\section{References}

[1] Benelli, G., Caselli, A., Di Giuseppe, G., Canale, A. (2017). Control of biting lice, Mallophaga a review. Acta Tropica. doi: 10.1016/j.actatropica.2017.05.031

[2] Brihadyrenko, V. V. (2003). Fundamentals of taxonomy of insects. Dnipropetrovsk, 204.

[3] Capinera, J. L. (Ed.) (2008). Encyclopedia of Entomology. Florida: Springer, 4346. doi: 10.1007/978-1-4020-6359-6

[4] Yatusevich, A. I., Stasukevich, S. I., Yatusevich, I. A., Michalochkina, E. I. (2006). Arachnoentomoses of domestic ruminants and odd-toed ungulates. Vitebsk: Vitebsk State Academy of Veterinary Medicine, 213.

[5] Veselkin, G. A. (1981). Measures of prevention and control against Zoophilous flies. Veterinaria Journal, 7, 24-35.

[6] Gurova, T. V. (2007). Prevention and measures improvement against siphunculatoses and bovicolosis of cattle. Kharkiv, 21.

[7] Stolbova, O. A., Hlazunova, L. A., Nikonov, A. A. et. al. (2014). Insects and ticks are parasites of cattle in the North Urals. Fundamental research, 11, 2650-2655.

[8] Berezovskyi, A. V., Pozhivil, A. I., Shevchenko, A. M. (2007). Modern medicine drugs for pharmacocorrection and animal chemoprophylaxis: Scientific issue. Kyiv, 240.

[9] Sivkov, G. S. (2001). Problems of animals protection against parasitic arthropods in Siberia. Probl. Entomol. and Arachnol, 42, 3-9.

[10] Herke, V. S., Herke, A. N. (2002). Some aspects of the general body reaction with ectoparasitosis. Actual problems of Veterinary Medicine. Issue of conference, dedicated to Anniversary of 300 years of Sankt-Peterburg “Zoosfera”, 70-73.

[11] Jazayeri, J. A. (2004). Biochemical studies on sheep body louse Bovicola ovis (Schrank) (Phthiraptera: Trichodectidae): comparison of pyrethroid and organophosphate resistant and susceptible strains. Pesticide Biochemistry and Physiology, 80 (1), 1-11. doi: 10.1016/j.pestbp.2004.05.002

[12] Yatusevich, A. I., Karassov, N. F., Michalochkina, E. I. et. al. (1992). Recommendations against parasitoses of ruminants. Vitebsk: Vitebsk State Academy of Veterinary Medicine, 11.

[13] Arkhipov, A. I. (2005). Rational methods of using antiparasitic drugs in veterinarinary. The Journal of Theory and practice of control parasitic diseases, 6, 51-52.

[14] Mashkey, I. A., Ponomarenko, V. Ya., Fedorova, O. V. (2003). Recommendations for diagnostic, treatment and prophylaxis of bovine teliaziosis. Kharkiv, 10.

[15] Kataeva, T. S., Burova, A. A. (1999). Techniques of insecticides usage for cattle. The Theory and Practice control against parasitic diseases Journal, 119-121.

[16] Recommendation to the study of efficacy of repellents and insecticides in Veterinary Medicine (1982). Moscow State Russian Academy of Agrarian Sciences, 13.

[17] Gandzyuk, V. N. (1990). Aerosols of pyrethroids against ectoparasites of cattle. Veterinariya, $1,21-22$.

[18] Shevchenko, A. V., Mezhenska, N. A., Tytarenko, Ya. M. (2015). Safety and quality of raw milk infected by Bovicola bovis cows. Scientific issue of the National University of Life \& Environmental Sciences of Ukraine, 221, 287-293.

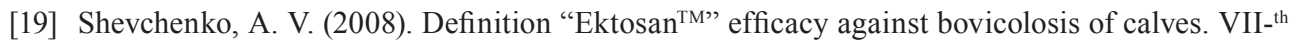
International Congress of Veterinarians, dedicated to 100 years Anniversary of the National Agricultural University of Ukraine, Kyiv, 21-24.

[20] Berezovskyi, A. V., Shevchenko, A. M., Katiukha, S. M. (2008). Determination of Ektosan ${ }^{\text {тм }}$ efficacy for the protection of bovine animals against blood sucker insects at condition Summer farmyard farming. Veterinary Medicine, 91, 47-50. 
[21] Berezovskyi, A. V., Shevchenko, A. M., Nahorna, L. V. (2008). Pat. No. 36437 UA. Insecticide and mite drug "Ektosan ${ }^{\mathrm{TM}}$ ". MPK A61K 31/01. No. u200806691; declareted: 15.05.2008; published: 27.10.2008, Bul. No. 20.

[22] Pavlov, S. D., Tsapirin, Yu. N., Tikhomirov, S. M. (1987). Ultra-low-volume spraying insecticides for animals against blood sucker insects. Ecology and geography of arthropods in Siberia. Nauka, 249-251.

[23] Pavlov, S. D., Pavlova, R. P. (2001). Determination of the effectiveness of insecticides with dosed contact of insects. Probl. Entomol. And arachnol, 43, 193-203.

[24] Tkachov, A. V. (2004). Pyrethroid insecticides are analogues of plants natural protection substances. Soros Educational Journal, 8 (2), 56-63.

[25] Zubarev, V. N., Sidorkin, V. A. (2013). Entomoses of cattle and measures of prophylaxis. Effectivnoe zhivotnovodstvo [Journal of efficacy husbandry], 6 (92), 25-26.

[26] Campbell, J. B., Boxler, D. J., Davis, R. L. (2001). Comparative efficacy of several insecticides for control of cattle lice (Mallophaga: Trichodectidae and Anoplura: Haematopinidae). Veterinary Parasitology, 96 (2), 155-164. Available at: https://www.ncbi.nlm.nih.gov/pubmed/11230922 doi: 10.1016/s03044017(00)00415-5

[27] Shevchenko, A. V., Soroka, N. M., Galat, V. F., Chornyi, V. A. (2010). Efficacy of Ektosan ${ }^{\mathrm{TM}}$ against animals ectoparasitoses. Scientific issue of the National University of Life \& Environmental Sciences, 151 (2), 206-208.

[28] Eldridge, B. F., Edman, J. D. (Eds.) (2004). Medical Entomology: A Textbook on Public Health and Veterinary Problems caused by Arthropods. Kluwer: University of California, 660. doi: 10.1007/978-94$007-1009-2$

[29] Wall, R., Shearer, D. (1997). Veterinary entomology: arthropod ectoparasites of veterinary importance. Veterinary Parasitology, 99-116. 